\title{
BUTYLTIN SPECIATION IN SEDIMENTS FROM TODOS OS SANTOS BAY (BAHIA, BRAZIL) BY GC-PFPD
}

Juliana Feitosa Felizzola, Angela de Luca Rebello Wagener*, Ana Cristina Almeida e Wei Oh Lin

Departamento de Química, Pontifícia Universidade Católica do Rio de Janeiro, Rua Marquês de São Vicente, 225, 22453-900, Rio de Janeiro - RJ, Brasil

Recebido em 2/2/07; aceito em 14/6/07; publicado na web em 9/11/07

\begin{abstract}
Butyltin compounds were investigated in surface sediments from 17 stations in Todos os Santos Bay. Analytical conditions for organotin determination in marine sediments were optimized for $\mathrm{GC}$ with pulsed flame photometric detection. Detection limits were: $5.4 \mu \mathrm{g} \mathrm{kg}^{-1}$ for TBT; $0.2 \mu \mathrm{g} \mathrm{kg}{ }^{-1}$ for DBT; and $2.1 \mu \mathrm{g} \mathrm{kg}^{-1}$ for MBT, using a 610-nm filter. In general, TBT concentrations were low and in the range of $\angle \mathrm{DL}$ to $15.9 \mu \mathrm{g} \mathrm{kg}^{-1}$. Only in one of the investigated stations DBT and MBT were above detection limit despite the oxic to slightly anoxic conditions in the sediments. The presence of paint particles in the sediments and degradation in the water column during resuspension events followed by removal of the more soluble DBT and MBT may explain these observations.
\end{abstract}

Keywords: butyltin speciation; sediments; Todos os Santos Bay.

\section{INTRODUCTION}

There is an increasing interest and concern about the wide spread use of antifouling paints containing tributyltin (TBT) ${ }^{1,2}$. Such substances intentionally used to eliminate certain organisms that infest ship hulls also act as endocrine disrupters in non target organisms leading to the appearance of imposex in gastropods and to reproductive failure ${ }^{1-8}$. Because of proven threats to marine organisms several countries banned or have imposed restrictions to the use of TBT although there are still doubts on the efficacy and possible adverse effects of alternative paints ${ }^{4,5}$.

In Brazil, no legislation is currently in place to control the use of TBT-based paints. Studies conducted in Guanabara Bay, Rio de Janeiro, that houses the second largest harbor in Brazil and several shipyards and marinas, showed concentrations of TBT in sediments as high as $500 \mu \mathrm{g} \mathrm{kg}^{-1}$. Also in Guanabara Bay Almeida et al report lack of evidences of TBT degradation in the anoxic sediments of the bay ${ }^{10}$. Limaverde showed that mussels and gastropods from the bay contain high concentrations of TBT and that imposex in Stramonita haemastoma results from exposition to TBT contaminated waters ${ }^{11}$. Godoi et al investigating butyltins in sediments from São Paulo coast found highest TBT levels in Santos harbor $\left(360 \mu \mathrm{g} \mathrm{kg}^{-1}\right.$ TBT) and in Guaruja marina $\left(670 \mu \mathrm{g} \mathrm{kg}^{-1} \mathrm{TBT}\right)^{12}$.

The aim of the present work was to extend the evaluation of TBT contamination in surface sediment of coastal Brazilian areas to the Todos os Santos Bay (TSB) located in the northeastern region of Brazil. Organotin speciation in sediments has been used to evaluate the extent of marine environment contamination as well as on going remobilization and degradation processes ${ }^{13}$.

With an area of approximately $1000 \mathrm{~km}^{2}$, the Todos os Santos Bay is the largest bay in the Brazilian coast. It has an extensive intertidal zone and a narrow opening to the ocean between Itaparica Island and Salvador City (Figure 1). The tidal regime, characterized by NNE high tidal currents and SSW low tidal currents, is the principal determining factor of water circulation within Todos os Santos Bay. This region is influenced by tropical climate with a well defined rain season from April to June. During summer, predominant winds are from SE, whereas during winter NE winds prevail ${ }^{14}$.
Since the 1950s, coastal areas of the Todos os Santos Bay have shown increasing industrialization. Exploitation of natural resources also increased along with the population living in the drainage basin ${ }^{15}$. Nowadays, effluents from 29 industries drain into the bay contributing, together with urban and port activities, to the pollution of several areas of the bay. Most of the present study was focused in the Northern and Eastern portions of Todos os Santos Bay (Figure 1) because of the presence of an oil refinery, a major harbor, an industrial district and several ports and anchorage points, all potential sources of organotin compounds. The main fluvial contributions to the bay are derived from the Paraguaçu and Subaé rivers but in the above regions only three small rivers are found, namely D. João, Mataripe and São Paulo rivers. All these rivers are crossing zones of abundant mangrove vegetation and carry wastes from several industries and urban areas ${ }^{16}$.

\section{EXPERIMENTAL}

\section{Reagents}

All reagents used were analytical grade. Tributyltinchloride (TBTCl) 96\%, dibutyltindichloride $\left(\mathrm{DBTCl}_{2}\right)$ 96\%, mono-

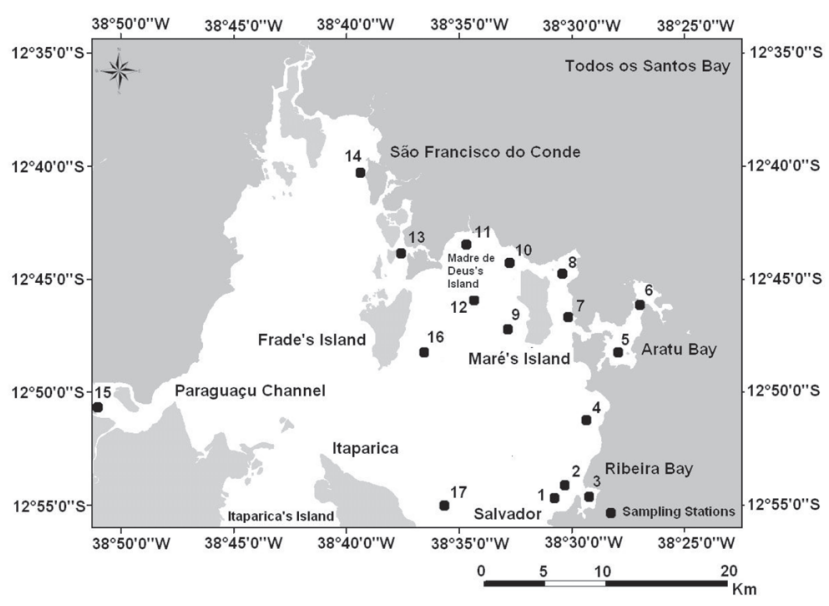

Figure 1. Todos os Santos map with sampling stations 
butyltintrichloride $\left(\mathrm{DBTCl}_{2}\right) 95 \%$, tetrabutyltin (TeBT) $93 \%$ and pentylmagnesiumbromide $\left(\mathrm{CH}_{3}\left(\mathrm{CH}_{2}\right)_{4} \mathrm{MgBr}\right.$, Grignard reagent) $2 \mathrm{~mol}$ $\mathrm{L}^{-1}$ in diethyl ether were purchased from Aldrich (Milwaukee, WI, USA). Tripropyltinchloride (TPrTCl) 98\%, neutral aluminum oxide $\left(\mathrm{Al}_{2} \mathrm{O}_{3}, 70-230 \mathrm{mesh}\right), \mathrm{Na}_{2} \mathrm{SO}_{4}, \mathrm{HOAc}$ and $\mathrm{HCl}$ were obtained from Merck (Darmstadt, Germany); ammonium pyrrolidinedithiocarbamate (APDC $-\mathrm{C}_{5} \mathrm{H}_{8} \mathrm{NS}_{2} \cdot \mathrm{NH}_{4}$ ) $97 \%$ was purchased from Fluka (Buchs, Switzerland), toluene and methyl alcohol (ChromAR ${ }^{\circledR}$ HPLC) from Malinckrodt, 95\% n-hexane HPLC/GC UltimAR ${ }^{\circledR}$ and acetone Nanograde from Malinckrodt or Merck; sílica gel $(0.063-0.200 \mathrm{~mm})$ and silver nitrate PA (ACS Iso) were from Merck. For organic carbon determination, $\mathrm{H}_{3} \mathrm{PO}_{4}$ (p. a., Merck) was used.

\section{Standard preparation}

Organotin chlorides and TeBT stock standard solutions were prepared at $1.000 \mathrm{mg} \mathrm{kg}^{-1}$ (as Sn) in hexane and remaining stable over a period of six months stored at $-20{ }^{\circ} \mathrm{C}$. Pentylated working solutions were prepared by diluting the stock solutions with hexane before derivatization with Grignard reagent.

\section{Sampling}

In January 2003, $5 \mathrm{~cm}$ of sediments were collected with a Van Veen sampler of 4.2 L specially designed to avoid sediment-water contact during retrieval. Sediments were collected at each station and sub-samples were separated for the determination of organotin compounds, organic carbon, grain size, $\mathrm{pH}$ and redox potential $\left(\mathrm{E}_{\mathrm{H}}\right)$, and thereafter immediately sealed and maintained in aluminum box at $4{ }^{\circ} \mathrm{C}$ during the transport to the laboratory. The sub-samples for organotin speciation and organic carbon determination were stored in the dark at $-20{ }^{\circ} \mathrm{C}$. In station 15 , sample was collected in July 2003 using a Kullenberg core sampler.

\section{Sample treatment}

Redox potential and $\mathrm{pH}$ were measured immediately after arrival in the laboratory using an $\mathrm{Ag} / \mathrm{AgCl} / \mathrm{Pt}$ combined electrode and a glass combined electrode, respectively. Measurements were performed under inert atmosphere, inserting the electrode directly in the sediment. The sub-samples for organotin and organic carbon determination were freeze-dried and ground before storing in amber glass bottles in the dark at $-20^{\circ} \mathrm{C}$. Samples were not sieved as to avoid contamination.

\section{Organic carbon determination}

Organic carbon was measured in 1-2 $\mathrm{g}$ of dry sediment, after acid treatment $\left(1: 2 \mathrm{H}_{3} \mathrm{PO}_{4}\right.$ aqueous solution, as recommended in the Shimadzu TOC manual) to eliminate carbonates. A Shimadzu SSM-5000A solid sample combustion unit coupled to a Shimadzu TOC-5000A Total Organic Carbon Analyzer was utilized for determination. Quantification was performed using analytical curves and potassium biphtalate as standard.

\section{Butyltins determination}

\section{Extraction}

The adopted extraction methodology (Figure 2) was modified from Abalos et al. and Fernández-Escobar et al. as appropriate to the sediments characteristics and to the detection by PFPD ${ }^{17-20}$. Two grams of sediment (dry mass) were transferred to a glass centrifuge tube. Tripropyltin chloride ( $\mathrm{TPrTCl}$ ) was added as surrogate at a spiking level of $0.2 \mathrm{~g}$. The extraction step was accomplished by sonication with toluene/HOAc (10:4, v/v) for $5 \mathrm{~min}$ followed by centrifugation at $2000 \mathrm{rpm}$, for $5 \mathrm{~min}$, and transfer of the supernatant to a separation vessel. This process was repeated twice.

To the extracts $10 \mathrm{~mL}$ of $0.5 \%$ APDC aqueous solution were added to partition the HOAc to the aqueous phase and improve the solubility of the mono- and disubstituted organotins in the organic phase. This step was repeated two more times and the separated organic phase was percolated through activated $\mathrm{Na}_{2} \mathrm{SO}_{4}$ and rotaevaporated to a few milliliters at about $38^{\circ} \mathrm{C}$.

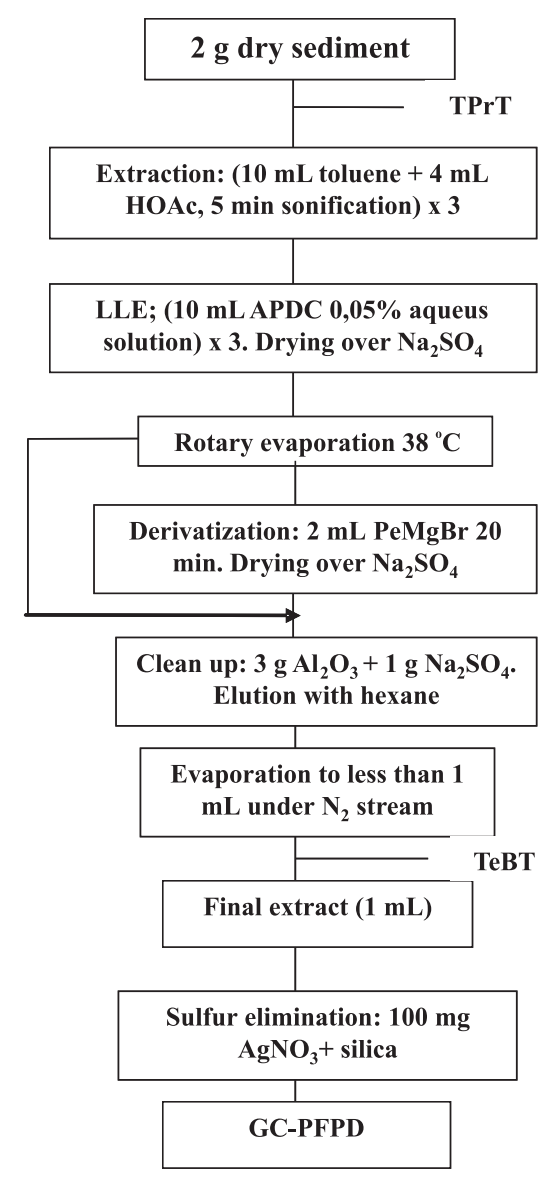

Figure 2. Flow diagram of the analytical procedure for organotin speciation

Derivatisation, alumina cleanup and sulfur elimination

After addition of $2 \mathrm{~mL}$ of Grignard reagent, the extract was shake for $1 \mathrm{~min}$ and left standing for $20 \mathrm{~min}$. Elimination of excess of Grignard reagent was carried out in an ice bath by adding $12 \mathrm{~mL}$ of Milli-Q water and $2 \mathrm{~mL}$ of concentrated $\mathrm{HCl}$. The derivatised extract was isolated with a Pasteur pipette and then percolated through activated $\mathrm{Na}_{2} \mathrm{SO}_{4}$, recovered in a vessel and rotaevaporated to a few milliliters at $38{ }^{\circ} \mathrm{C}$.

The cleanup was made by alumina adsorption chromatography in a glass column filled with $3 \mathrm{~g}$ of alumina, $2 \%$ water deactivated, and $1 \mathrm{~g}$ of activated $\mathrm{Na}_{2} \mathrm{SO}_{4}$ packed on the top. The organic phase was percolated through the column, using hexane as eluent, and the extract recovered was evaporated under a gentle stream of nitrogen down to $1 \mathrm{~mL}$ and TeBT was added as internal standard prior to the GC-PFPD determination. Finally, for sulfur elimination, $100 \mathrm{mg}$ of $25 \% \mathrm{AgNO}_{3}$ - coated sílica gel, were put into vials containing the concentrated extract $(1 \mathrm{~mL})$. After sonicating for 10 min the mixture was allowed to stand for $2 \mathrm{~h}$ at room temperature. 


\section{GC-PFPD determination}

A Varian CP-3800 gas chromatograph fitted with a 1177 split/ splitless injector, a 8200 auto sampler and a pulsed flame photometric detector (Varian, Walnut Creek, CA, USA) was used in the measurements. The injector kept at $250{ }^{\circ} \mathrm{C}$ was operated in splitless mode for $60 \mathrm{~s}$ following injection. Separation was performed on a DB-17 (50\%-phenyl-methylpolysiloxane) fused silica column of $30 \mathrm{~m}$ length, $0.25 \mathrm{~mm}$ internal diameter and 0.25 $\mu \mathrm{m}$ film thickness (J\&W Scientific, Folsom, CA, USA). Nitrogen (ultra pure; flow $1.7 \mathrm{~mL} \mathrm{~min}^{-1}$ ) was used as carrier gas. The following temperature program was used: $50^{\circ} \mathrm{C}$ for $1 \mathrm{~min}, 50$ to $80{ }^{\circ} \mathrm{C}$ at 50 ${ }^{\circ} \mathrm{C} \min ^{-1}, 80$ to $140{ }^{\circ} \mathrm{C}$ at $10^{\circ} \mathrm{C} \mathrm{min}^{-1}, 140$ to $170{ }^{\circ} \mathrm{C}$ at $2{ }^{\circ} \mathrm{C} \min ^{-1}$, 170 to $280{ }^{\circ} \mathrm{C}$ at $40{ }^{\circ} \mathrm{C} \mathrm{min}{ }^{-1}$, with a final hold of $5 \mathrm{~min}$. The detector, fitted with a Schott BG-17 band pass filter, was held at $300{ }^{\circ} \mathrm{C}$. The gas flow rates were: air, $17.1 \mathrm{~mL} \mathrm{~min}^{-1}$; air, $10.6 \mathrm{~mL}$ $\min ^{-1}$ and hydrogen, $13.5 \mathrm{~mL} \mathrm{~min}{ }^{-1}$. Best gate delay, gate width and trigger level tested in the laboratory were, respectively, $5 \mathrm{~ms}, 3 \mathrm{~ms}$ and $200 \mathrm{mV}$. The determinations were made in duplicate. The resulting chromatograms were quantified using peak area normalized to the internal standard using the Star Chromatography Workstation 5.52 software (Walnut Creek, CA, USA). A chromatogram demonstrating the good peak resolution is shown under Figure 3.

\section{Calibration and quantification}

Quantification was performed by internal standard procedure, using TeBT added after derivatisation. Standards were prepared in hexane containing 6-201 $\mathrm{g} \mathrm{L}^{-1}$ as $\mathrm{Sn}$ of pentylated butyltins (TBT, DBT, MBT). Procedural blanks were carried out for every batch of samples.

The analytical procedure was validated by analyzing the harbor sediment reference material PACS-2 from the National Research Council of Canada (Ottawa, Canada), certified for TBT and DBT. As shown in Table 1 results obtained for the certified material are in good agreement with the certified values. The parameters of the calibration curves for all analytes are given under Table 2. Butyltin concentrations were corrected for the recoveries of TPrT (from 70 to $100 \%$ ) used as surrogate. Derivatization yield tested in standard solutions of the several analytes was always around $85 \%$. Detection limits expressed as $\mu \mathrm{g} \mathrm{kg}^{-1}$ as Sn were: TBT (5.4), DBT (0.2) and MBT (2.1) ${ }^{21}$. The mean relative standard deviation obtained for 7 injections of standard solutions was $8.6 \%$ for TBT, $10.3 \%$ for DBT and $5.1 \%$ for MBT. Reported organotin concentrations are expressed as $\mu \mathrm{g} \mathrm{kg}^{-1}$ dry weight as $\mathrm{Sn}$ ( $\mu \mathrm{g}$ of tin per $\mathrm{kg}$ of dry sediment).

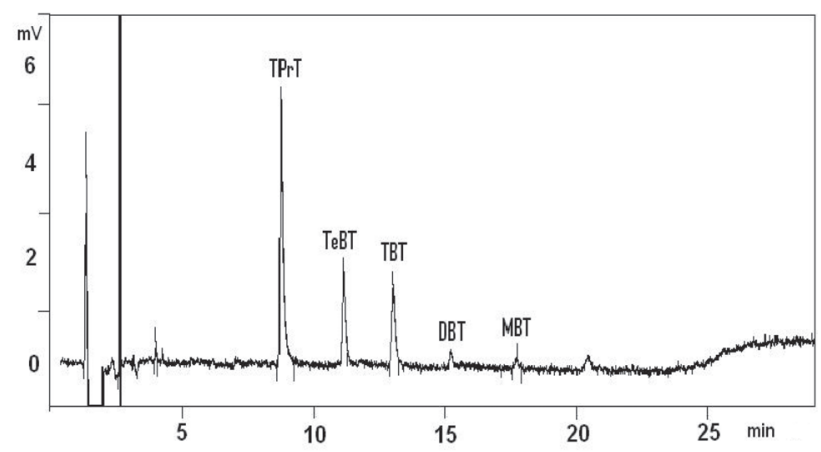

Figure 3. Chromatogram of a sample from Ponta do Marinho (station 7) obtained by using GC-PFPD; see text for analytical conditions. TBT, DBT. $M B T, T P r T$ and TeBT stand for, tributyltin, dibutyltin, monobutyltin, tripropyltin (surrogate), tetrabutyltin (internal standard), respectively. The peaks of DBT and MBT can be identified in this chromatogram but not quantified
Table 1. Butyltin concentrations in the reference material PACS-2 in $\mu \mathrm{g} \mathrm{kg}{ }^{-1}$ as $\mathrm{Sn}$ (dry weight)

\begin{tabular}{lcc}
\hline Compound & Determined Value $(\mathrm{n}=3)$ & Certified Value \\
\hline TBT & $1041.9 \pm 21.1(2.0)$ & $980 \pm 130$ \\
DBT & $1001.3 \pm 58.5(5.8)$ & $1090 \pm 150$ \\
MBT & $172.5 \pm 20.7(11.9)$ & $300^{\mathrm{a}}$ \\
\hline
\end{tabular}

a Information value; coefficient of variation, in percent, are given between brackets.

Table 2. Properties of the analytical curves

\begin{tabular}{lccc}
\hline OTs & $\begin{array}{c}\text { Linear range } \\
\left(\mu \mathrm{g} \mathrm{L}^{-1}\right)\end{array}$ & $\begin{array}{c}\mathrm{CV}^{*} \\
(\%)\end{array}$ & $\begin{array}{c}\text { Correlation } \\
\text { coefficient }(\mathrm{r})\end{array}$ \\
\hline TPrT & $120.91-201.53$ & 5.10 & 0.999 \\
TBT & $36.06-48.07$ & 5.47 & 0.998 \\
& $18.03-30.05$ & 9.38 & 0.990 \\
DBT & $30.03-60.06$ & 4.63 & 0.994 \\
MBT & $12.08-39.26$ & 4.14 & 0.993 \\
\hline
\end{tabular}

* Coefficient of variation obtained for the given concentration interval

\section{RESULTS AND DISCUSSION}

Results are given under Table 3 and the space distribution of concentrations appears in Figure 4. A remarkable result was the absolute dominance of TBT in all stations except in Bimbarras Sul (station 13) where TBT was below detection limit and DBT appeared as the main species. The predominance of TBT is usually associated to recent inputs. Spearman and Pearson statistical tests were applied to verify possible correlations between TBT and the other variables in Table 3. The absence of significant correlations indicates that processes controlling the concentration of TBT and its degradation products are occurring outside the sediment environment, as will be discussed below.

The degradation of TBT through dealkylation to tin occurs via biotic and abiotic reactions ${ }^{22}$. Photolysis is the most important abiotic degradation process with a half-life of about 3 months ${ }^{22}$. According to Batley and Maguire the half life for the biotic degradation of TBT in waters varies from 6 days to several weeks, while the total mineralization occurs within 50-75 days ${ }^{23,24}$. Only in anoxic sediments the degradation is significantly slower ranging from 2 years to decades ${ }^{23,24}$. Therefore, the virtual absence of TBT

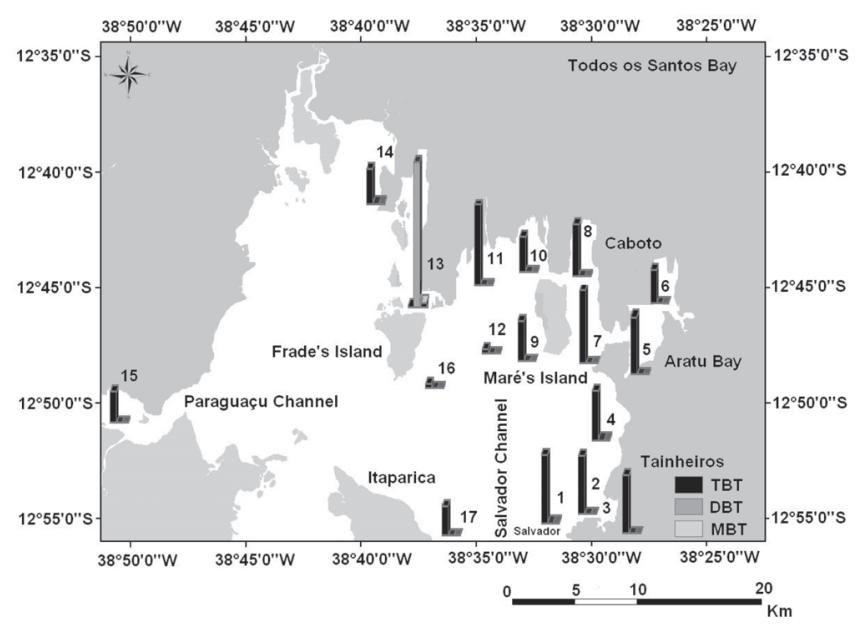

Figure 4. Space distribution of butyltin concentrations in the Todos os Santos Bay 
Table 3. OTs concentrations $\left(\mu \mathrm{g} \mathrm{kg}^{-1} \mathrm{dw}\right.$ as $\left.\mathrm{Sn}\right)$ in the sediment samples from Todos os Santos Bay, Bahia, Brazil

\begin{tabular}{|c|c|c|c|c|c|c|c|c|c|}
\hline \multirow[t]{2}{*}{ Sampling site } & \multirow[t]{2}{*}{$\mathrm{pH}$} & \multirow[t]{2}{*}{$\mathrm{E}_{\mathrm{H}(\mathrm{mV})}$} & \multirow{2}{*}{$\begin{array}{c}\text { Grain size } \\
<0.63 \mu \mathrm{m} \\
(\%)\end{array}$} & \multirow[t]{2}{*}{$\begin{array}{l}\mathrm{C}_{\text {org }} \\
(\%)\end{array}$} & \multicolumn{4}{|c|}{$\begin{array}{l}\text { Concentration } \\
\left(\mu \mathrm{g} \mathrm{kg}^{-1}\right)\end{array}$} & \multirow[t]{2}{*}{$\begin{array}{l}\text { TBT } \\
(\%)\end{array}$} \\
\hline & & & & & TBT & DBT & MBT & BTs & \\
\hline 1. Salvador Harbor & 7.25 & 53 & 8.70 & 0.74 & 13.5 & $<\mathrm{dl}$ & $<\mathrm{dl}$ & 13.5 & 100 \\
\hline 2. Itapagipe (2) & 7.79 & 341 & 3.21 & 5.46 & 11.7 & $<\mathrm{dl}$ & $<\mathrm{dl}$ & 11.7 & 100 \\
\hline 3. Tainheiros & 7.35 & 30 & 75.61 & 2.79 & 12.1 & $<\mathrm{dl}$ & $<\mathrm{dl}$ & 12.1 & 100 \\
\hline 4. Paripe & 7.32 & 21 & 72.28 & $4 . .59$ & 9.6 & $<\mathrm{dl}$ & $<\mathrm{dl}$ & 9.6 & 100 \\
\hline 5. Aratu Bay (South) & 7.46 & 48 & 41.17 & 2.78 & 11.6 & $<\mathrm{dl}$ & $<\mathrm{dl}$ & 11.6 & 100 \\
\hline 6. Aratu Bay (North) & 7.35 & 22 & 89.15 & 1.99 & 6.7 & $<\mathrm{dl}$ & $<\mathrm{dl}$ & 6.7 & 100 \\
\hline 7. Ponta do Marinho & 7.19 & 55 & 98.09 & 2.30 & 14.7 & $<\mathrm{dl}$ & $<\mathrm{dl}$ & 14.7 & 100 \\
\hline 8. Caboto (North) & 7.49 & 89 & 87.46 & 2.33 & 10.2 & $<\mathrm{dl}$ & $<\mathrm{dl}$ & 10.2 & 100 \\
\hline 9. Ponta da Cacimba & 7.42 & 35 & 80.13 & 0.73 & 7.8 & $<\mathrm{dl}$ & $<\mathrm{dl}$ & 7.8 & 100 \\
\hline 10. Maré/São Paulo & 7.29 & 32 & 93.98 & 2.91 & 7.0 & $<\mathrm{dl}$ & $<\mathrm{dl}$ & 7.0 & 100 \\
\hline 11. Mataripe & 7.26 & -248 & 55.40 & 1.33 & 15.9 & $<\mathrm{dl}$ & $<\mathrm{dl}$ & 15.9 & 100 \\
\hline 12. Maré/channe & 7.29 & 72 & 63.58 & 1.73 & 5.5 & $<\mathrm{dl}$ & $<\mathrm{dl}$ & 5.5 & 100 \\
\hline 113. Bimbarras Sul & 7.17 & -15 & 28.51 & 1.62 & $<\mathrm{dl}$ & 28.8 & 4.0 & 32.8 & $<\mathrm{dl}$ \\
\hline 14. Near Fontes Island & 6.74 & 32 & 95.43 & 2.33 & 6.9 & $<\mathrm{dl}$ & $<\mathrm{dl}$ & 6.9 & 100 \\
\hline $\begin{array}{l}\text { 15. Near Porcos Island } \\
\text { in Iguape Bay }\end{array}$ & 7.44 & 24 & 13.95 & 3.27 & 6.2 & $<\mathrm{dl}$ & $<\mathrm{dl}$ & 6.2 & 100 \\
\hline 16. Near Frades Island & 7.69 & 110 & 3.61 & 2.68 & 5.5 & $<\mathrm{dl}$ & $<\mathrm{dl}$ & 5.5 & 100 \\
\hline 17. Salvador Channel & 7.89 & 55 & 3.61 & 3.81 & 6.0 & $<\mathrm{dl}$ & $<\mathrm{dl}$ & 6.0 & 100 \\
\hline
\end{tabular}

The BT concentrations for each site are the average of two determinations per sample; standard deviations are in the range of 0.1 to $2.3 \mu \mathrm{g} \mathrm{kg}{ }^{-1}$. dl (detection limit): TBT $=5.4 \mu \mathrm{g} \mathrm{kg}^{-1}$, DBT $=0.2 \mu \mathrm{g} \mathrm{kg}^{-1}$ and MBT $=2.1 \mu \mathrm{g} \mathrm{kg}^{-1}$. Depth (m) of the water column in stations 1 through 17: 19.0, 4.0, 5.0, 16.0, 4.0, 3.5, 4.5, 3.0, 3.0, 7.0, 7.5, 15.0, 3.4, 10.0, 5.5, 3.0, 4.0.

degradation products in sediments, which in its majority can be considered slightly anoxic, is not expected. In Guanabara Bay, where sediments are strongly anoxic, TBT is also the dominant species although DBT and MBT are found in detectable concentrations $\mathrm{s}^{910}$.

In the Todos os Santos Bay (TSB) the combination of shallow water depths (average of $6 \mathrm{~m}$ ), high water transparence (relatively low concentration of suspended matter, 2.15-10.07 $\mathrm{mg} \mathrm{L}^{-1}$ ) and high water turbulence caused by winds and tidal currents may concur for the observed results ${ }^{25}$. Fent found from studies in seawater that 95-99\% of the total TBT is present in the dissolved phase ${ }^{2}$. Berg et al. described the adsorption-desorption behavior of TBT in sediments as a fast and reversible process involving mainly particulate organic matter ${ }^{26}$. In TSB the low availability of particles of organic nature $\left(0.13\right.$ to $\left.1.3 \mathrm{mg} \mathrm{L}^{-1}\right)$ is a factor that contributes to increasing residence time of these labile compounds in the water phase $^{25}$. In as much, according to the above cited authors any resuspension of contaminated sediments will enhance organotin concentrations in the water phase. Page et al. and Waite et al. also showed that significant amounts of TBT and DBT are liberated in the water column if contaminated sediments are resuspended ${ }^{27,28}$. Under such a circumstance DBT and MBT may be lost preferentially from the sediment due to the higher solubility as compared to TBT ( $\log \mathrm{K}_{\mathrm{ow}}$, octanol-water partitioning coefficient, is 2.40 for TBT, 1.50 for DBT and 0.40 for $\mathrm{MBT})^{29}$. It is possible that the generally low concentrations of TBT and the virtual absence of DBT and MBT in TSB (for some samples DBT and MBT peaks were present in the chromatogram as Figure 3 shows but were too small to allow accurate area measurement) may derive from frequent resuspension of sediments favoring dissolution in the water phase and photolytic or biotic degradation of organotins. Most probably TBT found in the sediments is a residual fraction associated in paint particles which are difficult to degrade. This hypothesis would also explain the absence of DBT and MBT in the sediments.

Organotin compounds (OT) seem to settle down in the vicinities of the sources (harbors, marinas, etc $)^{10,12}$. The space distribution in the TSB whereby higher TBT concentrations are in sites of potential sources confirms such a tendency. Stations 9, 10, 12, 14, 15, 16 and 17 where lower concentration were found are in areas under influence of the main tidal currents that enter the bay through the Salvador Channel. The lower values may result from the distance from major sources as well as from current driven dispersion in the water phase prior to sedimentation. It is interesting to note that station 14 in the near of the Subae River and where high sedimentation rates $\left(1.3 \mathrm{~cm}_{\text {year }}{ }^{-1}\right)$ are observed shows low TBT concentrations although there is abundant boat traffic in the area ${ }^{25}$. Station 7 in the Aratu Harbor presents the second higher TBT concentration, even if smaller by orders of magnitude than the 742 $\mu \mathrm{g} \mathrm{kg}^{-1}$ reported for sediments from an area influenced by the Rio de Janeiro Harbor ${ }^{10}$. Salvador Harbor (station 1), Itapagipe (station 2) and Tanheiros (station 3) are areas of intense navigation and show relatively higher concentrations although not proportional to the existing potential sources. Lessa et al. report presence of strong tidal currents and winds especially in the area of the Salvador Harbor, which may contribute for resuspension and for OT losses from sediments as already discussed above ${ }^{30}$.

Waite and co-workers proposed a criterion for classification of sediments according to their TBT contamination level ${ }^{28}$. Through such criterion, sediments containing from $<10 \mu \mathrm{g} \mathrm{kg}^{-1}$ TBT as Sn to $50 \mu \mathrm{g} \mathrm{kg}^{-1}$ can be considered slightly contaminated. The Brazilian legislation does not set limits for TBT in sediments but the recently approved Resolution 357 established $0.01 \mu \mathrm{g} \mathrm{L}^{-1} \mathrm{TBT}$ as standard for saline waters ${ }^{31}$.

Table 4 shows data from other areas of the globe, which in some cases are of the order of those found for TSB. The lowest values reported by Godoi et al for the coast of São Paulo were found in Cananeia, a rather pristine area where, however, fishing and leisure boats are present ${ }^{12}$. In Guanabara Bay and in the sites examined by Godoi et al. in São Paulo sediments were anoxic and peak concentrations were found associated to marinas and harbors as reported for most of the other studied areas in the globe. 
Table 4 . Examples of OT concentrations reported for different areas of the world ( $\mu \mathrm{g} \mathrm{kg}^{-1}$ as $\left.\mathrm{Sn}\right)$

\begin{tabular}{lcccc}
\hline Location & TBT & DBT & MBT & Ref. \\
\hline Western Mediterranean & nd -9260 & nd -960 & nd -1591 & 32 \\
Perth, Australia & $1.0-1350$ & n.i. & n.i. & 33 \\
Auckland, New Zealand & $4.9-3318$ & n.i. & n.i. & 34 \\
The Netherlands & $8.8-3900$ & $<2.0-5800$ & $<1.5-260$ & 35 \\
Sta. Monica, USA & nd -7.4 & nd -27 & nd -12 & 36 \\
Otsuchi Bay, Japan & $5.6-82$ & n.i. & n.i. & 37 \\
Coast of India & nd -1280 & $17-394$ & $1.6-393$ & 38 \\
Coast of São Paulo, Brazil & $17-847$ & nd -921 & $36-367$ & 12 \\
Guanabara Bay, Brazil & nd -742 & $3.8-310$ & nd -21 & n.0 -360 \\
Coast of Malaysia & $2.8-1100$ & nd -395 & nd & 39 \\
Guanabara Bay, Brazil & $10-522$ & nd -28.8 & nd -4.0 & This work \\
TSB, Brazil & nd -15.9 & & &
\end{tabular}

nd $=$ not detected; n.i. $=$ not informed

\section{CONCLUSIONS}

The presence of TBT as the dominant OT species in TSB is a rare feature since even in anoxic environments, where TBT is more stable, measurable levels of DBT and MBT have been reported for other areas. TBT concentrations are relatively low even in areas of intense navigation. The combination of these two facts leads to the conclusion that TBT released into the water is rapidly degraded, possibly to tin, before reaching final sedimentation. TBT half life under the environmental conditions of the Todos os Santos Bay may be remarkably smaller than those so far reported in the literature. The fraction that resists degradation must be embedded in a protective medium, most probably paint particles. These results show that monitoring contamination and possible hot spots in TSB needs a different strategy given that concentration records in sediments do not discriminate sites in the near of potential sources from others. Measurements in the water column or in organisms that accumulate TBT or adversely react to its presence at low concentration, as for instance gastropods that develop imposex, are more appropriate for use in future environmental assessments.

\section{ACKNOWLEDGEMENTS}

The authors are grateful to $\mathrm{CNPq}$ (Conselho Nacional de Desenvolvimento Científico e Tecnológico) for the financial support, to the Environmental Resources Coordination of the State of Bahia and to Hydros Eng. for the right to use the samples. J. Felizzola acknowledges the support of CAPES (Coordenação de Aperfeiçoamento de Pessoal de Nível Superior).

\section{REFERENCES}

1. Hoch, M.; Appl. Geochem. 2001, 16, 719.

2. Fent, K.; Crit. Rev. Toxicol. 1996, 261.

3. Wilken, R. D.; Kuballa, J.; Jantzen, E.; Fresenius. J. Anal. Chem. 1994, $350,77$.

4. Alzieu, C.; Sanjuan, J.; Deltreil, J. P.; Borel, M.; Mar. Pollut. Bull. 1986, $17,494$.

5. Champ, M.; Sci. Total Environ. 2000, 258, 21.

6. Gibbs, P. E.; Bryan, G. W. In Organotin - Environmental Fate and Effects; Champ, M. A.; Seligman, P. F., eds.; Chapman \& Hall: London, 1996, p. 259.

7. Horigushi, T.; Shiraishi, H.; Shimizu, M.; Masatoshi, M.; Appl. Organomet. Chem. 1997, 11, 451 .

8. Abbott, A.; Abel, P. D.; Arnold, D. W.; Milne, A.; Sci. Total Environ. 2000, 258,5 .

9. Fernandez, M.; Wagener, A. de L. R.; Limaverde, A. M.; Scofield, A. de L.; Pinheiro, F. M.; Rodrigues, E.; Mar. Environ. Res. 2005, 59, 435.
10. Almeida, A. C.; Wagener, A. de L. R.; Maia, C. B.; Miekeley, N.; Appl. Organomet. Chem. 2004, 18, 694.

11. Limaverde, A. M.; Ph.D. Thesis, Pontifícia Universidade Católica do Rio de Janeiro, Brazil, 2003.

12. Godoi, A. F. L.; Montone, R. C.; Santiago-Silva, M.; J. Chromatogr., A 2003, 985, 205.

13. Watanabe, N.; Takatsuki, H.; Sukai, S.; Appl. Organomet. Chem. 1997, 11, 273.

14. Ponce, V. R.; Correa, C. I.; An. Hidrograficos 1980, 37, 113.

15. Tavares, T. M.; Rocha, V. C.; Porte, C.; Barceló, D.; Albaiges, J.; Mar. Pollut. Bull. 1988, 19, 575.

16. Venturini, N.; Tommasi, L. R.; Mar. Pollut. Bull. 2004, 48, 97.

17. Abalos, M.; Bayona, J. M.; Capañó, R.; Granados, M.; Leal, C.; Prat, M. D.; J. Chromatogr., A 1997, 788, 1.

18. Abalos, M.; Bayona, J. M.; Quevauviller, P.; Appl. Organomet. Chem.1998, 12,541 .

19. Fernández-Escobar, I.; Gibert, M.; Messeguer, A.; Bayona, J. M.; Anal. Chem. 1998, 70, 3703.

20. Jacobsen, J. A.; Stuer-Lauridsen, F.; Pritzl, G.; Appl. Organomet. Chem. 1997, 11, 737.

21. Currie, L. A.; Anal Chim. Acta 1999, 391, 105.

22. Maguire, R. J.; Tkacz, R. J.; Chau, Y. K.; Bengert, G. A.; Wong, P. T. S.; Chemosphere 1986, 15, 253.

23. Batley, G. In Tributyltin: A Case Study of an Environment Contaminant; de Mora, S.J., ed.; Cambridge University Press: Cambridge, 1996, p. 139.

24. Maguire, R. J. In ref. 23, p. 94

25. CRA; Diagnóstico da Concentração de Metais Pesados e Hidro-carbonetos de Petróleo nos Sedimentos e Biota da Baía de Todos os Santos, Centro de Recursos Ambientais da Bahia, Salvador, 2004, vol. II.

26. Berg, M.; Arnold, C. G.; Müller, S. R.; Mühlmann, J.; Schwarzenbach, R. P.; Environ. Sci. Technol. 2001, 35, 3151.

27. Page, D. S. ; Widdows, J.; Environ. Pollut. 1996, 91, 237.

28. Waite, M. E.; Waldock, M. J.; Thain, J. E.; Smith, P. J.; Milton, S. M.; Mar. Environ. Res. 1991, 32, 89.

29. Vighi, M.; Calamari, D.; Chemosphere 1985, 14, 1925.

30. Lessa, G. C.; Lima, G. M.; Carvalho, J. B.; Oliveira, W.; http:// www.cpgg.ufba.br/ glessa/bts, accessed in January 2005.

31. Conselho Nacional de Meio Ambiente; Resolução CONAMA No 357 , Brasília, DF, 2005.

32. Tolosa, I.; Merlini, L.; De Bertrand, N.; Bayona, J. M ; Environ. Toxicol. Chem. 1992, 11, 145.

33. Burt, J. S.; Ebell, G. F.; Mar. Pollut. Bull. 1995, 30, 723.

34. De Mora, S. J.; Phillips, D. R.; Mar. Pollut. Bull.. 1995, 30, 50.

35. Stab, J. A.; Traas, T. P.; Stroomberg, G.; van Kesteren, J.; Leonards, P.; van Hutten, B.; Th. Brinkman, U. A.; Cofino, W. P.; Arch. Environ. Contam. Toxicol. 1996, 31, 319.

36. Venkatesan, M. I.; Chalaux, N.; Bayona, J. M.; Zeng, E.; Environ. Pollut. 1998, 99, 263.

37. Takahashi, S.; Tanabe, S.; Takeuchi, I.; Miyazaki, N.; Arch. Environ. Contam. Toxicol. 1999, 37, 50 .

38. Rajendran, R. B.; J. Environ. Monit. 2001, 3, 627.

39. Sudaryanto, A.; Takahashi, S.; Iwata, H.; Tanabe, S.; Ismail, A.; Environ. Pollut. 2004, 130, 347 